\title{
Copper Zinc Sulfur Compound Solar Cells Fabricated by Spray Pyrolysis Deposition for Solar Cells
}

\author{
Noriyuki Kitagawa $^{1}$, Seigo Ito ${ }^{1 *}$, Duy-Cuong Nguyen $^{1}$, Hitoshi Nishino $^{2}$ \\ ${ }^{1}$ Department of Electric Engineering and Computer Sciences, University of Hyogo, Hyogo, Japan; ${ }^{2}$ Energy Technology Laboratories, \\ Osaka Gas Co., Ltd., Osaka, Japan. \\ Email: ${ }^{*}$ itou@eng.u-hyogo.ac.jp
}

Received January $16^{\text {th }}, 2013$; revised February $17^{\text {th }}, 2013$; accepted February $26^{\text {th }}, 2013$

\begin{abstract}
$\mathrm{Cu}-\mathrm{Zn}$-S (CZS) films were deposited by the spray pyrolysis method. As-deposited CZS film showed a low crystallinity. The resistivity of CZS film with $\mathrm{Cu} /(\mathrm{Cu}+\mathrm{Zn})$ ratio of $50 \%$ is around $10^{-2} \Omega \cdot \mathrm{cm}$. The CZS film elements using spray $\mathrm{Cu}-\mathrm{Zn}(=1: 1)$ solution with thiourea was confirmed as $\mathrm{Cu}: \mathrm{Zn}: \mathrm{Sn}=2: 2: 3$ by ICP-MS and EDX. The band gap of CZS films was varied in the range of $1.8-3.5 \mathrm{ev}$ when the $\mathrm{Cu} /(\mathrm{Cu}+\mathrm{Zn})$ ratio was increased from $0 \%$ to $67 \%$; CZS film with $\mathrm{Cu} /(\mathrm{Cu}+\mathrm{Zn})$ ratio of $50 \%$ showed an wide band gap of $2 \mathrm{eV}$. The photovoltaic characteristics were confirmed with cell structure of $\left\langle\right.$ Glass $/ \mathrm{FTO} / \mathrm{TiO}_{2} / \mathrm{In}_{2} \mathrm{~S}_{3} / \mathrm{CZS} /$ carbon $\rangle$. The best cell was observed at the CZS films with $\mathrm{Cu} /(\mathrm{Cu}+\mathrm{Zn})$ ratio of $50 \%$; these cells depicted a conversion efficiency of $1.7 \%$.
\end{abstract}

Keywords: $\mathrm{Cu}_{2} \mathrm{Zn}_{2} \mathrm{~S}_{3}$; Spray Pyrolysis; Solar Cells; Superstrate Structure; $\mathrm{TiO}_{2}$

\section{Introduction}

Compound solar cells as $\mathrm{Cu}(\mathrm{InGa}) \mathrm{Se}_{2}$ (CIGS), $\mathrm{CuInS}$ (or $\mathrm{Se})_{2}$ (CIS) solar cells have shown high durable and high efficiency (Record efficiency 20.3\%) [1]. These solar cells have been normally fabricated by vacuum method. The vacuum process has the high cost of equipment and low process speed for production. In addition, the CIS and CIGS solar cells use expensive materials as gallium and indium. Therefore, $\mathrm{Cu}-\mathrm{Zn}-\mathrm{Sn}-\mathrm{S}(\mathrm{Se})$ compound (CZTSSe) which does not use indium has been developed recently (the record efficiency $10.1 \%$ ) [2]. The advantage of CZTSSe solar cells is using non-vacuum method and without expensive materials. However, CZTS solar cell using four or five elements including $\mathrm{Cu}, \mathrm{Zn}$, $\mathrm{Sn}, \mathrm{S}$, and Se, is so complex. For this reason, we have tried to develop $\mathrm{Cu}-\mathrm{Zn}$-S compound (CZS) with three elements for absorber layer in solar cells; this compound can be simpler in comparison with CZTS. Some groups reported about this material for applications in Inorganic Electro-Luminescence $[3,4]$ or just basic research as semiconductor [5-7]. In our work, the CZS films were prepared by spray pyrolysis method, which is non-vacuum and low cost. This is the first report of CZS for applications in solar cells.

"Corresponding author.
In this paper, we fabricated CZS films with different $\mathrm{Cu} /(\mathrm{Cu}+\mathrm{Zn})$ ratios. Optical, electrical and photovoltaic properties were analyzed in detail. Conversion efficiency of $1.72 \%$ was obtained at CZS solar cells with $\left\langle\right.$ carbon/CZS $/ \mathrm{In}_{2} \mathrm{~S}_{3} / \mathrm{TiO}_{2} / \mathrm{FTO} /$ glass $\rangle$ structure.

\section{Experimental}

The CZS layers were prepared on glass substrates by spray pyrolysis. The spray solution included $150 \mathrm{mM}$ of $\mathrm{SC}\left(\mathrm{NH}_{2}\right)_{2}$ and $60 \mathrm{ml}$ of $\mathrm{Cu}-\mathrm{Zn}$ source

$\left(\mathrm{CuCl}_{2}+\mathrm{Zn}\left(\mathrm{NO}_{3}\right)_{2}\right)$. The $\mathrm{Cu} /(\mathrm{Cu}+\mathrm{Zn})$ ratios varied in the range of $0 \%-67 \%$. The solution $(30 \mathrm{ml})$ was sprayed onto the substrates at temperature of $277^{\circ} \mathrm{C}$ in air ambience. The formation of the CZS crystal was confirmed by X-ray diffraction (XRD; Miniflex 2, Rigaku using $\mathrm{CuK} \alpha$ radiation) measurement. The shapes and elemental ratio of CZS crystals were measured using a TEM-EXD system (JEM2100F, JEOL Co. Ltd.). The composition of CZS film was also measure by inductively coupled plasma-mass spectroscopy (ICP-MS). The resistivity of CZS films was calculated from sheet resistance four-probe measurement. The carrier concentration and mobility were obtained by Hall-effect measurement (ResTest8300, Toyo Technica Co. Ltd.). The absorption spectra of CZS films were measured by ultraviolet-visi- 
ble spectroscopy (Lambda 750 UV/VIS, Perkin-Elmer). The distribution of elements including $\mathrm{Cu}, \mathrm{Zn}, \mathrm{In}, \mathrm{S}$ and $\mathrm{Ti}$ in the cell cross-section was confirmed by an electron probe micro-analyzer (EPMA). Photovoltaic measurements employed an AM 1.5 solar simulator equipped with a xenon lamp (YSS-100A, Yamashita Denso, Japan). The power of the simulated light was calibrated to 100 $\mathrm{mW} \cdot \mathrm{cm}^{-2}$ by using $\mathrm{Si}$ solar cell reference. CZS solar cells with structure of

$\left\langle\right.$ carbon $/ \mathrm{CZS} / \mathrm{In}_{2} \mathrm{~S}_{3} / \mathrm{TiO}_{2} / \mathrm{FTO} /$ glass $\rangle$ were fabricated. $300 \mathrm{~nm}-\mathrm{In}_{2} \mathrm{~S}_{3}$ buffer layer and $500 \mathrm{~nm}-\mathrm{TiO}_{2}$ compact layers were also fabricated by spray pyrolysis method. Carbon paste was printed on cells as back electrode. Cells were scratched except just under back electrode. Figure 1 shows the samples before and after scratching.

\section{Results and Discussions}

The composition of the sprayed CZS films measured by Inductively Coupled Plasma (ICP) and TEM-EDX is $\mathrm{Cu}_{3.9} \mathrm{Zn}_{3.8} \mathrm{~S}_{5.9}$ and $\mathrm{Cu}_{28.65} \mathrm{Zn}_{27.37} \mathrm{~S}_{43.95}$, respectively; these elemental results are concluded to $\mathrm{Cu}_{2} \mathrm{Z}_{2} \mathrm{~S}_{3}(\mathrm{CZS})$, which corresponds to the ion number of $\mathrm{Cu}^{+}$and $\mathrm{Zn}^{2+}$. In spite of the deposition under ambient atmosphere, $\mathrm{Cu}$ was become $\mathrm{Cu}^{+}$, but not oxidized to $\mathrm{Cu}^{2+}$. This is due to the effect of thiourea.

Figure 2(a) shows a TEM image of spray-pyrolysis CZS. It can be observed that some parts of CZS were crystalized to $c a .10 \mathrm{~nm}$ particles. The electron diffraction pattern (Figure 2(b)) shows the Debye-Scherrer ring, which suggests that the spray-pyrolysis CZS is the aggregate of nanoparticles. For the comparison, a TEM image of CZS by ball-milling synthesis is shown (Figure 2(c)). The ball-milling CZS particles were $c a .100 \mathrm{~nm}$, and the particle was close to a single crystal, judged from the diffraction pattern (Figure 2(d)).

Figure 3 shows the variation of the resistivity of CZS films with different $\mathrm{Cu} /(\mathrm{Cu}+\mathrm{Zn})$ ratios. The resistivity of CZS films is rather low. The resistivity was increased with decreasing $\mathrm{Cu}$ concentration from $67 \%$ to $18.7 \%$. Below $18.7 \%$, we cannot measure the resistivity because of the high resistance of CZS films.

By the Hall-effect measurement using a CZS film with $\mathrm{Cu} /(\mathrm{Cu}+\mathrm{Zn})=50 \%$, the CZS was a p-type semiconductor, and the carrier concentration and mobility was 3.06 $\times 10^{21} \mathrm{~cm}^{-3}$ and $1.37 \times 10^{-1} \mathrm{~cm}^{2}(\mathrm{~V} \cdot \mathrm{s})^{-1}$, respectively

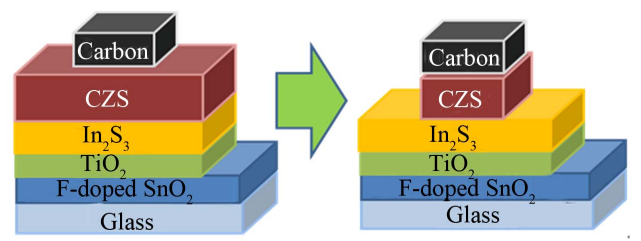

Figure 1. Solar cell structures before and after scratching the CZS layer.
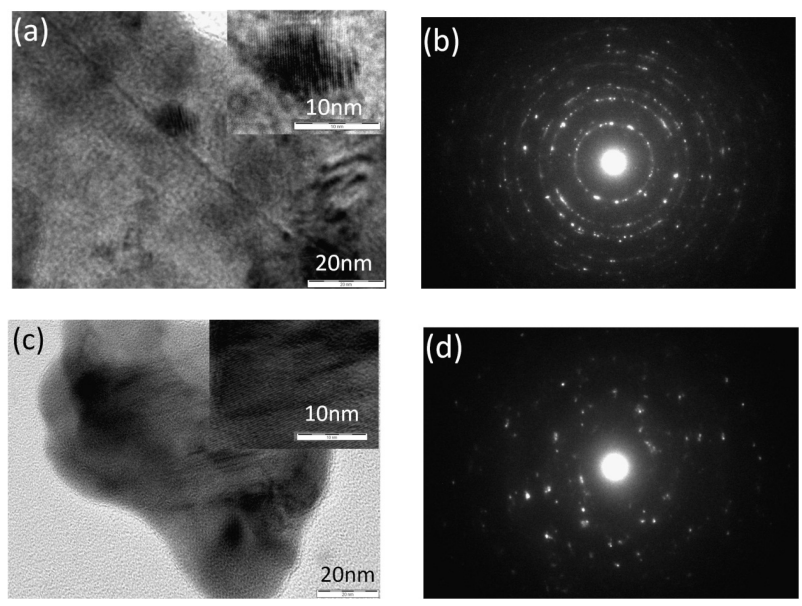

Figure 2. A TEM image (a) and an electron diffraction pattern (b) of CSZ by spray pyrolysis deposition, and a TEM image (c) and an electron diffraction pattern (d) of CSZ by ball-milling synthesis.

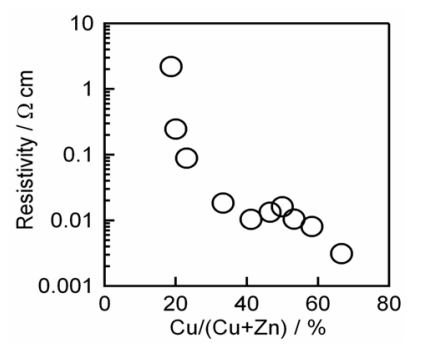

Figure 3. Resistivity of CZS films with different $\mathrm{Cu} /(\mathrm{Cu}+\mathrm{Zn})$ ratios.

The carrier concentration was quite high as a p-type semiconductor, which may due to the surface defect on the CZS nano crystal.

Figure 4(a) shows a plot of absorption coefficient as a function of photon energy $(h c / \lambda)$ for the CZS film with different $\mathrm{Cu} /(\mathrm{Cu}+\mathrm{Zn})$ ratios. The band gap of CZS films was shifted towards low energy with increasing $\mathrm{Cu}$ concentration. The variation of CZS band gap value with $\mathrm{Cu} /(\mathrm{Cu}+\mathrm{Zn})$ ratio was shown in Figure 4(b). The band gap value varied in the range from $1.8 \mathrm{eV}$ to $3.6 \mathrm{eV}$ with the variation of $\mathrm{Cu} /(\mathrm{Cu}+\mathrm{Zn})$ ratios from $67 \%$ to $0 \%$. The results indicate that $\mathrm{CZS}$ is wide band gap materials.

Figure 5 shows EPMA results on cross-section of the $\mathrm{Cu} /(\mathrm{Cu}+\mathrm{Zn})=50 \%$ films. The result showed that copper diffused into $\mathrm{In}_{2} \mathrm{~S}_{3}$ layer, but zinc did not diffuse into $\mathrm{In}_{2} \mathrm{~S}_{3}$ layer. It was speculated that a thin layer of $\mathrm{CuInS}_{2}$ may be formed at the interface between CZS and $\mathrm{In}_{2} \mathrm{~S}_{3}$; $\mathrm{CuInS}_{2}$ and $\mathrm{In}_{2} \mathrm{~S}_{3}$ can make $\mathrm{p}$-n junction and the cells can generate electricity [8]. However, typical $\mathrm{CuInS}_{2}$ peaks $(2 \theta=27.9,46.3,55 . \square)$ were not observed from the results as shown in Figure 6. Since the $\mathrm{CuInS}_{2}$ layer is too thin, the XRD system could not detect the $\mathrm{CuInS}_{2}$ peaks. 
The photocurrent-voltage of CZS cells with and without scratching was shown in Figure 7(a). The CZS layer of this cell was prepared with $\mathrm{Cu} /(\mathrm{Cu}+\mathrm{Zn})$ ratio of $50 \%$. After scratching, the photocurrent became lower than the sample without scratching. Figure 7(b) shows photocurrent-voltage of $\mathrm{CuInS}_{2}$ (CIS) spray cells with and without scratching for comparison. After scratching, the photocurrent did not change in the CIS solar cell with the sample without scratching the CIS layer. Therefore,
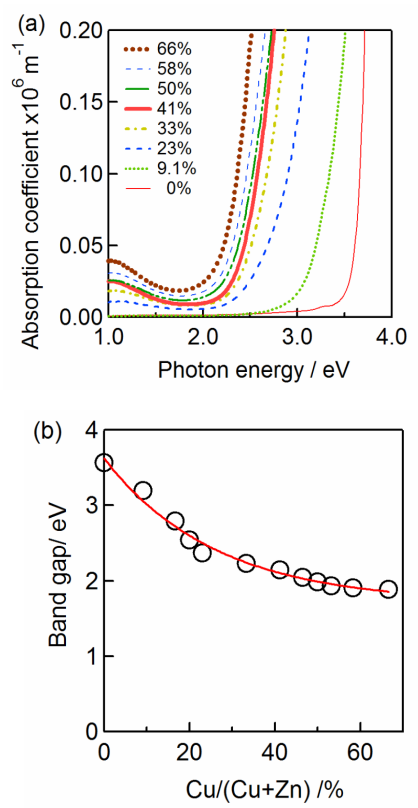

Figure 4. CZS absorption spectra (a) and the band gap variation (b) of $\mathrm{CZS}$ with different $\mathrm{Cu} /(\mathrm{Cu}+\mathrm{Zn})$ ratios.

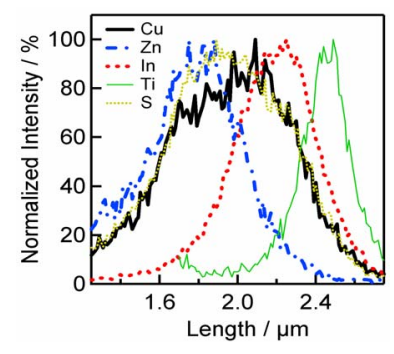

(a)

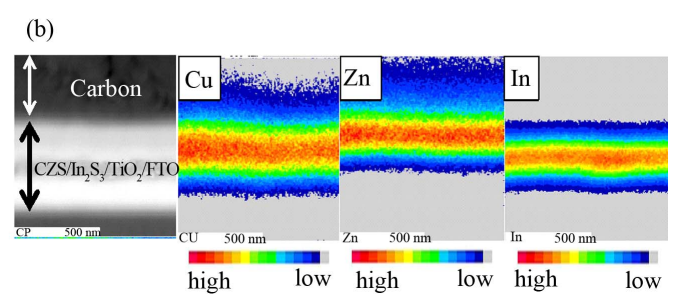

Figure 5. Electron probe micro analysis (EPMA) spectra (a) and the elemental mapping images (b) of $\left\langle\mathrm{CZS} / \mathrm{In}_{2} \mathrm{~S}_{3} / \mathrm{TiO}_{2} / \mathrm{FTO} /\right.$ glass $\rangle$ on cross-section at $\mathbf{C u} /(\mathbf{C u}+\mathbf{Z n})=\mathbf{5 0} \%$.

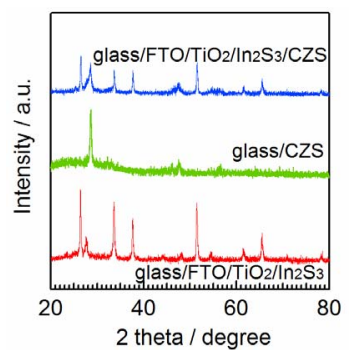

Figure 6. X-ray diffraction patterns of $\left\langle\right.$ glass $\left./ \mathrm{FTO} / \mathrm{TiO}_{2} / \mathrm{In}_{2} \mathrm{~S}_{3} / \mathrm{CZS}\right\rangle$, $\langle$ glass $/ \mathrm{CZS}\rangle$ and $\left\langle\right.$ glass $\left./ \mathrm{FTO} / \mathrm{TiO}_{2} / \mathrm{In}_{2} \mathrm{~S}_{3}\right\rangle$.

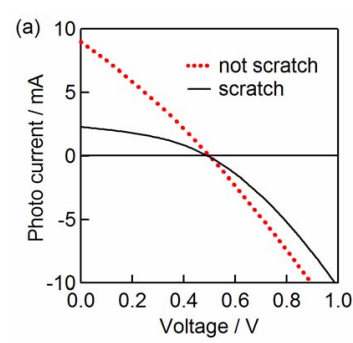

(c)

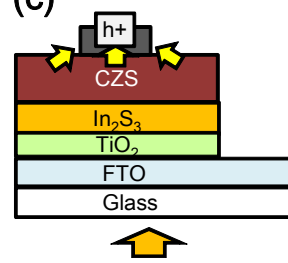

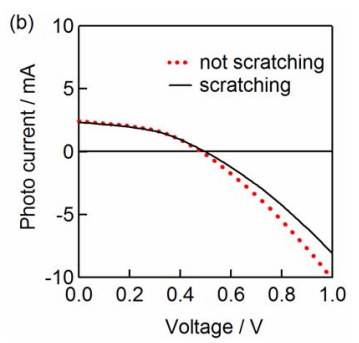

(d)

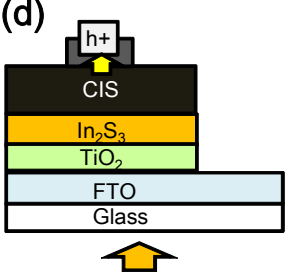

Figure 7. Photovoltaic characteristics of CIS and CZS solar cells with/without scratching. I-V curves of $\mathrm{Cu} /(\mathbf{C u}+\mathbf{Z n})=50 \% \quad \mathrm{CZS}$ (a) and $\mathrm{CuInS}_{2}$ (b) solar cells with and without scratching. The schemes of electron flow in CZS (c) and CIS (d) solar cells.

the difference of CZS photocurrent was due to the high conductivity of CZS films, which can collect the generated holes effectively from the surrounding (Figure 7(c)). On the other hand, the conductivity of $\mathrm{CuInS}_{2}$ layer was lower (ca. $0.1 \Omega^{-1} \cdot \mathrm{cm}^{-1}$ ), and the hole were able to be transferred from the $\mathrm{CuInS}_{2}$ layer just under the back electrode (Figure 7(d)).

Figure 8 shows the variation of conversion efficiency of CZS solar cells with $\mathrm{Cu} /(\mathrm{Cu}+\mathrm{Zn})$ ratios. The conversion efficiencies, which were lower than $0.5 \%$ in the range below $33 \%$ and over $67 \%$ of $\mathrm{Cu} /(\mathrm{Cu}+\mathrm{Zn})$ ratio, performed over $1 \%$ from $42 \%$ to $58 \%$ of $\mathrm{Cu} /(\mathrm{Cu}+\mathrm{Zn})$ ratio. The cells at $50 \%$ ratio of $\mathrm{Cu} /(\mathrm{Cu}+\mathrm{Zn})$ showed the peak of photoenergy conversion efficiencies.

Figure 9 shows the current density-voltage curves of the best cell with $\mathrm{Cu} /(\mathrm{Cu}+\mathrm{Zn})$ ratio of $50 \%$. The shortcircuit photocurrent $\left(J_{\mathrm{Sc}}\right)$, open-circuit photovoltage (Voc), fill factor and conversion efficiencies were $9.12 \mathrm{~mA} \cdot \mathrm{cm}^{-2}$, $0.492 \mathrm{~V}, 0.383$ and $1.72 \%$, respectively. It was noticed 


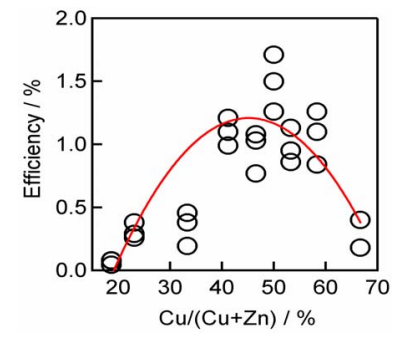

Figure 8. The variation of photoenergy conversion efficiencies of $\mathrm{CZS}$ solar cells with different $\mathrm{Cu} /(\mathrm{Cu}+\mathrm{Zn})$ ratios.

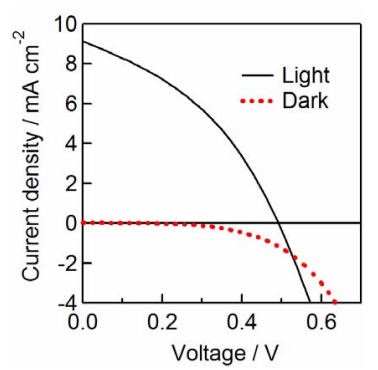

Figure 9. Current density-voltage curves of a best cell with $\mathrm{Cu} /(\mathrm{Cu}+\mathrm{Zn})=\mathbf{5 0} \%$ under light $\left(\mathrm{AM} 1.5,100 \mathrm{~mW} \cdot \mathrm{cm}^{-2}\right)$ and dark conditions. The cell area was

$25 \mathrm{~mm}^{2}(=5 \mathrm{~mm} \times 5 \mathrm{~mm})$.

that the dark and light curves indicate crossing point at $0.53 \mathrm{~V}$. This crossing point suggests double diode interfaces in a solar cell [9].

\section{Conclusion}

CZS films were deposited by spray pyrolysis at $277^{\circ} \mathrm{C}$ in air ambience. The resistivity of CZS films increases with decreasing copper concentration. The band gap of CZS films varied in the range from 1.8 to 3.5 when $\mathrm{Cu} /(\mathrm{Cu}+\mathrm{Zn})$ ratio changed in the range from $67 \%$ to $0 \%$. A strong diffusion of $\mathrm{Cu}$ atom from $\mathrm{CZS}$ layer into In2S3 layer was observed. The diffusion of $\mathrm{Cu}$ atom from CZS into $\mathrm{In}_{2} \mathrm{~S}_{3}$ may form a thin CIS layer between $\mathrm{CZS}$ and $\mathrm{In}_{2} \mathrm{~S}_{3}$. The best efficiency of $1.27 \%$ was obtained at CZS cells with $\mathrm{Cu} /(\mathrm{Cu}+\mathrm{Zn})$ ratio of $50 \%$.

\section{Acknowledgements}

A part of this work was supported by NEDO (Japan).

\section{REFERENCES}

[1] P. Jackson, D. Hariskos, E. Lotter, S. Paetel, R. Wuerz, R. Menner, W. Wischmann and M. Powalla, "New World Record Efficiency for $\mathrm{Cu}(\mathrm{In}, \mathrm{Ga}) \mathrm{Se}_{2}$ Thin-Film Solar Cells beyond 20\%," Progress in Photovoltaics: Research and Applications, Vol. 19, No. 7, 2011, pp. 894-897. doi:10.1002/pip. 1078

[2] D. Aaron, R. Barkhouse, O. Gunawan, T. Gokmen, T. K. Todorov and D. B. Mitzi, "Device Characteristics of a $10.1 \%$ Hydrazine-Processed $\mathrm{Cu}_{2} \mathrm{ZnSn}(\mathrm{Se}, \mathrm{S})_{4}$ Solar Cell Photovoltaic," Progress in Photovoltaics: Research and Applications, Vol. 20, No. 1, 2012, pp. 6-10.

[3] J. Huang, Y. Yang, S. Xue, B. Yang, S. Liu and J. Shen, "Photoluminescence and Electroluminescence of $\mathrm{ZnS}: \mathrm{Cu}$ Nanocryttals in Polymeric Networks," Applied Physics Letters, Vol. 70, No. 18, 1997, pp. 2335-2337. doi:10.1063/1.118866

[4] W. Q. Peng, G. W. Cong, S. C. Qu and Z. G. Wang, "Synthesis and Photoluminescence of $\mathrm{ZnS}: \mathrm{Cu}$ Nanoparticles," Optical Materials, Vol. 29, No. 2-3, 2006, pp. 313317. doi:10.1016/i.optmat.2005.10.003

[5] M. A. Yildirim, A. Ateș and A. Astam, "Annealing and Light Effect on Structural, Optical Properties of $\mathrm{CuS}$, $\mathrm{CuZnS}$ and $\mathrm{ZnS}$ Thin Films Grown by the SILAR Method," Physica E, Vol. 41, No. 8, 2009, pp. 1365-1372. doi:10.1016/j.physe.2009.04.014

[6] C. C. Uhuegbu, E. B. Babatunde and C. O. Oluwafemi, "The Study of Copper Zinc Sulphide $\left(\mathrm{CuZnS}_{2}\right)$ Thin Films," Turkish Journal of Physics, Vol. 32, No. 1, 2008 pp. 39-47.

[7] C. C. Uhuegbu and E. B. Babatunde, "Spectral Analysis of Copper Zinc Sulphide Ternary Thin Film Grown by Solution Growth Technique," American Journal of Scientific and Industrial Research, Vol. 1, No. 3, 2010, pp. 397-400. doi:10.5251/ajsir.2010.1.3.397.400

[8] T. Ryo, D.-C. Nguyen, M. Nakagiri, N. Toyoda, H. Matsuyoshi and S. Ito, "Characterization of Superstrate Type $\mathrm{CuInS}_{2}$ Solar Cells Deposited by Spray Pyrolysis Method," Thin Solid Films, Vol. 519, No. 21, 2011, pp. 7184-7188. doi:10.1016/j.tsf.2010.12.176

[9] J. Gao, J. M. Luther, O. E. Semonin, R. J. Ellingson, A. J. Nozik and M. C. Beard, "Quantum Dot Size Dependent $\mathrm{J}-\mathrm{V}$ Characteristics in Heterojunction $\mathrm{ZnO} / \mathrm{PbS}$ Quantum Dot Solar Cells," Nano Letters, Vol. 11, No. 3, 2011, pp. 1002-1008. doi: $10.1021 / \mathrm{nl} 103814 \mathrm{~g}$ 